\title{
DAMPAK PENGALIH FUNGSIAN LAHAN HUTAN JATI MENJADI LAHAN PERTANIAN JAGUNG TERHADAP KONDISI SOSIAL EKONOMI MASYARAKAT DI SEKITAR KECAMATAN KATOBU KABUPATEN MUNA
}

\author{
Syahrill Hidayat ${ }^{1}$ \\ ${ }^{1}$ Alumni Pendidikaan Geografi Universitas Halu Oleo
}

\begin{abstract}
Abstrak : Penelitian ini bertujuan untuk Dampak Pengalih fungsiaan Lahan Hutan Jati Menjadi Lahan Pertanian Jagung Terhadap Kondisi Sosial Ekonomi Oleh Masyarakat Di Sekitar Wilayah Kecamatan Katobu,Kabupaten Muna. Jenis penelitian ini adalah jenis penelitian deskriptif kualitatif. Teknik pengumpulan data yang di gunakan adalah pengamatan,angket, wawancara dan dokumentasi. Data di peroleh dari 43 informan. Keadaan social ekonomi di lihat dari 43 responden, yang memiliki kondisi kesehatan yang baik sebanyak 27 responden atau dalam persentase $63 \%$, Tingkat keamanan dapat di uraikan dari 43 responden yang merasa tidak aman sebanyak 17 responden atau dalam persentase $40 \%$, Di lihat dari interaksi sosial, responden yang memiliki interaksi sosial yang baik semakin banyak. Hal ini di lihat responden yang memiliki interaksi sosial yang baik sebanyak 39 responden atau dalam persentase $91 \%$.Di lihat dari luas lahan hutan jati warangga adalah sekitar $\pm 130 \mathrm{Ha}$, sedangkan yang di gunakan dalam lahan pertanian jagung sadalah sekitar \pm 10 Ha.Dari 43 responden jumlah pendapatan petani jagung yang mempunyai pndapatan setiap kali panen sebesar Rp 1. 500,000 - Rp 2. 000,000 adalah 18 responden atau dalam persentase $42 \%$.
\end{abstract}

Kata Kunci :Sosial Ekonomi, Lahan Pertanian Jagung, Cara 


\title{
THE IMPACT OF THE CONVERSION OF TEAK FOREST LAND INTO CORN FARMING LAND TO THE SOCIO-ECONOMIC CONDITIONS OF PEOPLE WHO LIVE IN KATOBU DISTRICT
}

\author{
Syahrill Hidayat ${ }^{1}$ \\ ${ }^{1}$ Alumni Of Halu Oleo University Geography Education
}

\begin{abstract}
This study aims to impact the conversion of teak forest land into corn farming land on the socio-economic conditions by communities around Katobu District, Muna District. This type of research is a type of qualitative descriptive research. Data collection techniques used are observation, questionnaires, interviews and documentation. Data obtained from 43 informants. The socioeconomic situation is seen from 43 respondents, who have good health conditions as many as 27 respondents or in the percentage of $63 \%$, the level of security can be described from 43 respondents who feel unsafe as many as 17 respondents or in the percentage of $40 \%$, seen from social interaction, respondents who have good social interaction are increasing. This is seen by respondents who have good social interaction as many as 39 respondents or in the percentage of $91 \%$. Looked at the width of the forest area of Warangga teak is about $\pm 130 \mathrm{Ha}$, while the one used in the sad corn farm is about \pm $10 \mathrm{Ha}$. respondents the amount of income of corn farmers who have income every time of harvest is Rp. 1. 500,000 - Rp. 2,000,000 is 18 respondents or in the percentage of $42 \%$.
\end{abstract}

\section{Keywords: Socio-Economic, Corn Farm Land, Way}

\section{PENDAHULUAN}

Hutan merupakan kesatuan ekosistem berupa hamparan lahan yang di dominasi oleh pepohonan berisi sumber daya hayati dan non hayati dalam persekutuan alam lingkungan, yang satu dengan lainnya tidak dapat di pisahkan. Hutan sebagai sekumpulan ekosistem di mana saling berhubungan erat antara hutan dan lingkungan baik itu berupa pepohonan, benda-benda hayati dan non hayati, lingkungan pendukung ( jasa ) hutan secara keseluruhan merupakan kumpulan hidup alam hayati beserta alam lingkungannya. Keanekaragaman hayati dalam suatu kawasan hutan alam terdapat beragam dan tingkat kerapatan yang tidak teratur dan bertumbuhan (Muhammad Dika Yudhistira,2013).

Sebagai salah satu contoh alih fungsi lahan yang terjadi adalah di wilayah Kecamatan Katobu, Kabupaten Muna. Kecamatan Katobu itu sendiri merupakan salah satu dari kecamatan yang terdapat di Kabupaten Muna. Sebagian dari masyarakatnya telah membangun rumah tempat tinggal dan menjadikan lahan pertanian jagung. Hal ini di perlukan adanya perhatian dari pemerintah ,terutama pemerintah 
daerah dalam melakukan antisipasi sebelum terjadinya alih fungsi lahan yang tidak terkendali.

Pengalihan fungsi lahan atau lazimnya disebut sebagai konversi lahan adalah perubahan fungsi sebagian atau seluruh kawasan lahan dari fungsinya semula (seperti yang di rencanakan) menjadi fungsi lain yang menjadi dampak negative (masalah) terhadap lingkungan dan potensi lahan itu sendiri .Alih fungsi lahan juga dapat diartikan sebagai perubahan untuk penggunaan lain disebabkan oleh faktor-faktor yang secara garis besar meliputi keperluan untuk memenuhi kebutuhan penduduk yang makin bertambah jumlahnya dan meningkatnya tuntutan akan mutu kehidupan yang lebih baik (Herman Soesangobeng, 2002).

Alih fungsi lahan sawah ke penggunaan lain telah menjadi salah satu ancaman yang serius terhadap keberlanjutan swasembada pangan. Intensitas alih fungsi lahan masih sulit dikendalikan, dan sebagian besar lahan sawah yang beralih fungsi tersebut justru yang produktivitasnya termasuk kategori tinggi-sangat tinggi. Lahan-lahan tersebut adalah lahan sawah beririgasi teknis atau semi teknis dan beralokasi di kawasan pertanian dimana tingkat aplikasi teknologi dan kelembagaan penunjang pengembangan produksi padi telah maju (Tati Nurmala,dkk. 2012).

\section{Menurut Notohadiprawiro}

Tejoyuwono. (2006), dampak sosial masyarakat akibat pengalih fungsiaan lahan hutan jati menjadi lahan pertanian jagung adalah : (1) Interaksi social,(2) Tingkat keamanan,(3) Kesehatan, (4) Luas lahan.

\section{Interaksi Sosial}

Kata interaksi berasal dari bahasa inggris yakni interaction yang terdiri dari inter dan action. Inter artinya antara dan action artinya tindakan. Jadi interaksi dapat di artikan bahwa interaksi merupakan tindakan antara satu sama lain. Menurut kamus ilmiah opular interksi adalah hal sewaktu melakukan aksi, hubungan, mempengaruhi antar hubungan. Dengan demikian interaksi adalah suatu tindakan antara sat sama lain yang berhubungan dan saling mempengaruhi (Barbara Agusti ).

\section{Tingkat Keamanan}

Masalah keamanan merukan salah satu aspek penting dari semuah kehidupan sosial. Menurut Kamus Besar Bahasa Indonesia, keamanan adalah keadaan aman atau ketentraman.

\section{Kesehatan}

Undang - undang Nomor 36 Tahun 2009 tentang kesehatan yaitu kesehatan di defenisiskan sebagai keadaan sehat baik secara fisik, mental, spiritual, maupun sosial yang menunjukan setiap orang untuk hidup produktif secara sosial dan ekonomis. Badan Pusat Statistik ( 2001 : 68 ) m,enjelaskan bahwa untuk melihat tingkat kesejahteraan suatu masyarakat dari segi kesehatannya. Sebagai penanggung jawab pelayanan kesehatan bagi masyarakat maka pemerintah terus berusaha meningkatkan kualitas pelayanan kesehatan. Untuk meningkatkan pelayanan kesehatan kepada masyarakat, pemerintah berusaha 
menyediakan berbagaio sarana dan prasarana kesehatan seperti puskesmas utama, puskesmas pembantu, dan posyandu serta tenaga medis maupun para medis seperti dokter, perawat, dan tenaga bidan, hal ini di lakukan untuk meningkatkan perilaku hidup bersih dan sehat, mencegah dan memberantas penyakit, meningkatkan keadaan gizi masyarakat dan meningkatkan masalah kesehatan.

\section{Luas Lahan}

Istilah lahan di gunakan berkenaan dengan permukiman bumi beserta segenap karateristik karateristik yang ada padanya dan penting bagi perikehidupan manusia (Soemarwoto. 2003.). Secara lebih rinci, istilah lahan atau land dapat di definisikan sebagai suatu wilayah di permukaan bumi, mencakup semua komponen biosfer yang dapat di anggap tetap atau bersifat simklis yang berada di atas dan di bawah wilayah tersebut termasuk atmosfer, tanah, batuan induk, relief, hidrologi, tumbuhan dan hewan, serta segala akibat yang di timbulkan oleh aktivitas manusia di masa lalu dan sekarang, yang kesemuanya itu berpengaruh terhadap penggunaan lahan oleh manusia pada saat sekarang dan di masa mendatang

Mishabul Munir, 2008 dampak ekonomi adalah pendapatan. pendapatan dari seorang warga masyarakat adalah hasil penjualanny dari hasil-hasil produksi yang dimilikinya kepada sektor produksi (Urip Santoso 2005). Disini pendapatan seseorang diartikan hasil penjualan faktor-faktor produksi yang dimilikinya, ini mengandung pengertian bahwa besar kecilnya pendapatan seseorang akan di tentukan oleh dua hal yaitu : a. Jumlah faktor-faktor produksi atau kekayaan yang dimilikinya.

b. Harga jual perunit dari setiap kekayaan atau faktor-faktor produksi yang dimiliki

Menurut Soekartiwi, 1995, Pendapatan / keuntungan merupakan selisih antara penerimaan perusahaan dan biaya total :

$$
\begin{gathered}
\mathrm{P}=\mathrm{TR}-\mathrm{TC} \\
\mathrm{TR}=\mathrm{Q} \mathrm{XH} \\
\mathrm{TC}=\mathrm{TFC}+\mathrm{TVC}
\end{gathered}
$$

Keterangan :

$\mathrm{P}=$ Pendapatan

$\mathrm{TR}=$ Total Penerimaan

$\mathrm{TC}=$ Total Biaya

\section{METODE PENELITIAN}

Penelitian ini telah di laksanakan diwilayah Kecamatan Katobu Kabupaten Muna pada bulan Mei 2018 sampai selesai.

Populasi dalam penelitian ini adalah seluruh masyarakat petani jagung yang tinggal di Wilayah Kecamatan Katobu, Kabupaten Muna sebanyak $43 \mathrm{KK}$.

Penentuan sampel penelitian ini adalah seluruh masyarakat petani di Wilayah Kecamatan Katobu, Kabupaten Muna sebanyak 43 KK.

Penelitian ini adalah jenis penelitian deskriptif kualitatif yaitu untuk mendeskripsikan dampak pengalihfungsian lahan hutan jati menjadi lahan pertanian jagung oleh masyarakat di sekitar wilayah Kecamatan Katobu Kabupaten Muna. 
Variabel yang di teliti adalah :
a. Kesehatan
b. Luas lahan
c. Tingkat keamanan
d. Interaksi sosial
e. Pendapatan

Dalam penelitian ini pengumpulan data di lakukan dengan cara sebagai berikut:

a. Pengamatan (observasi) yaitu aktifitas dalam koleksi data dengan cara mengamati dan mencatat mengenai kondisi objek penelitian.

b. Wawancara ( interview), yaitu melakukan tanya jawab dengan para informan untuk memperoleh data mengenai kondisi sosial ekonomi petani jagung. Selain wawancara terstruktur, data penelitian di lakukan, wawancara bebas dengan para informan dan sebagian responden.

c. Dokumentasi dalam penelitian ini di lakukan untuk mengamati secara langsung sehinga dapat mendeskripsikan kondisi yang sebenarnya dan mengambil gambar/foto di lokasi penelitian di lokasi tersebut.

Teknik analisis data yang di gunakan adalah teknik deskriptif kualitatif, sesuai dengan kebutuhan yang menjelaskan tentang keadaan sesunguhnya mengenai dampak pengalihfungsiaan lahan hutan jati warangga menjadi lahan pertanian jagung oleh masyarakat di sekitar wilayah Kecamatan Katobu Kabupaten Muna.

Teknik analisis data penelitian ini menggunakan rumus:

$$
\mathrm{P}=\frac{F}{N} \mathrm{X} 100 \%
$$

(Mukhtar Dan Erna Widodo,2000)

Keterangan :

$\mathrm{P}=$ kategori

$F=$ frekuensi (jumlah responden yang memilih alternatif yang sama)

$\mathrm{N}=$ jumlah responden

$100 \%=$ presentase

2.1 Tabel Kisi-Kisi Instrumen

\begin{tabular}{|c|c|c|c|c|}
\hline No & $\begin{array}{l}\text { Variabel } \\
\text { Penelitian } \\
\text { Indikator }\end{array}$ & & $\begin{array}{l}\text { Item } \\
\text { pertanyaan }\end{array}$ & $\begin{array}{l}\text { Jumlah } \\
\text { Pertanyaan }\end{array}$ \\
\hline \multirow[t]{4}{*}{1} & \multirow{4}{*}{$\begin{array}{l}\text { Dampak pengalihan } \\
\text { fungsian lahan hutan jati } \\
\text { menjadi lahan pertanian } \\
\text { jagung di sekitar wilayah } \\
\text { Kecamatan } \\
\text { Kabupaten Muna }\end{array}$} & Kesehatan & $1,2,3,4,5$ & 5 \\
\hline & & Luas lahan & 6,7 & 2 \\
\hline & & $\begin{array}{l}\text { Tingkat } \\
\text { keamanan }\end{array}$ & $8,9,10,11$ & 4 \\
\hline & & $\begin{array}{l}\text { Intreaksi } \\
\text { sosial }\end{array}$ & 12,13 & 2 \\
\hline
\end{tabular}

\begin{tabular}{cl}
\hline Sumber : Data diolah 2018 & \\
Instrumen penelitian ini di & fungsiaan Lahan Hutan Jati Menjadi \\
gunakan sebagai acuan dalam & Lahan Pertanian Jagung Oleh \\
pengumpulan data yang di lakukan & Masyarakat Di Sekitar Wilayah \\
dengan membagikan daftar pertanyaan & Kecamatan Katobu, Kabupaten \\
berupa angket kepada responden untuk & Muna.Angket yang di sediakan terdiri \\
mendeskripsikan Dampak Pengalih & dari 13 butir pernyataan.
\end{tabular}




\section{GAMBARAN UMUM LOKASI PENELITIAN}

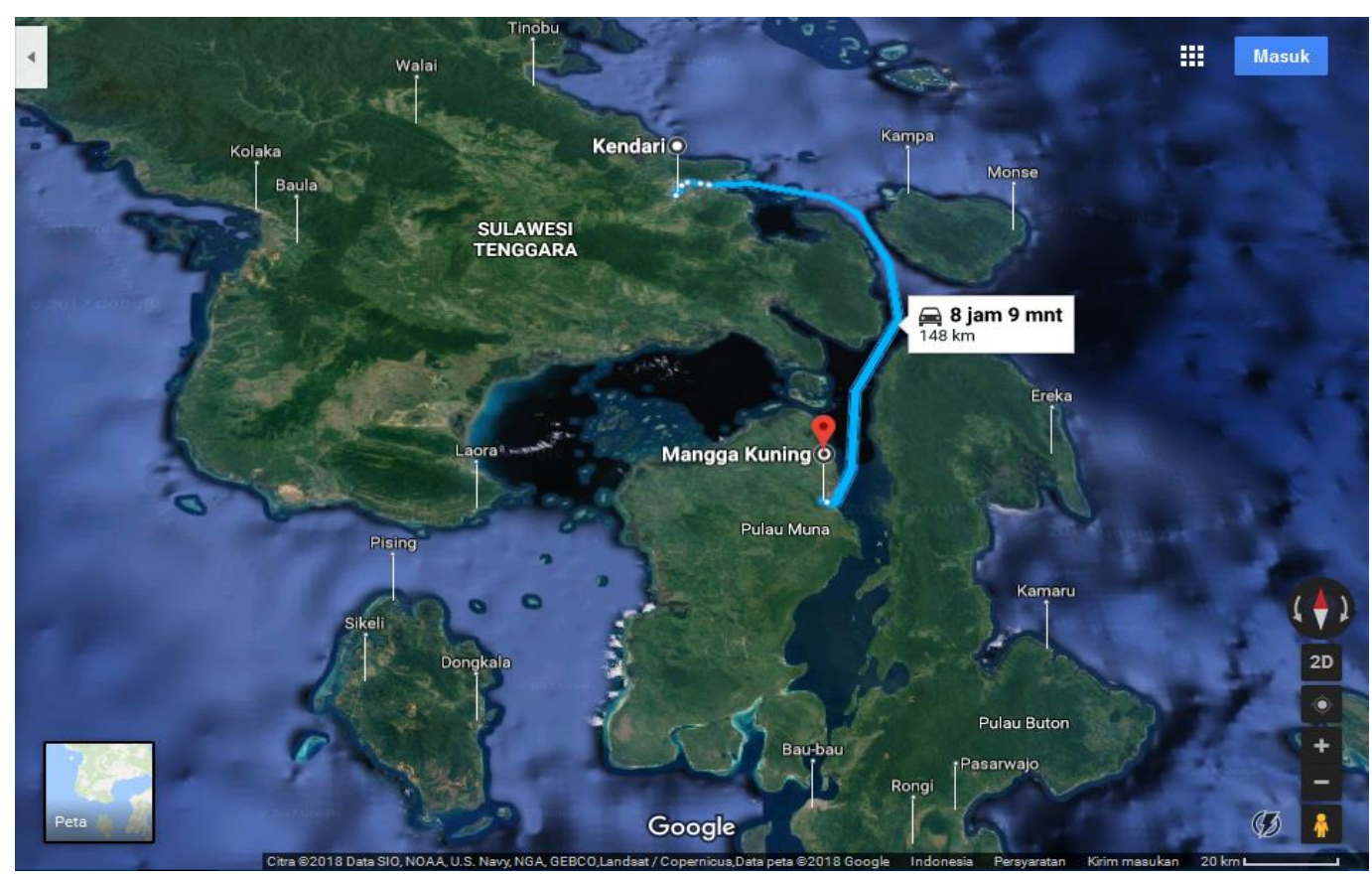

Gambar 3.1 Lokasi Penelitian

Kondisi Geografis

Secara astronomis, Kecamatan Katobu terletak dibagian Selatan Pulau Muna. Secara geografis,Katobu terletak di bagian selatan garis khatulistiwa, memanjang dari utara ke selatan diantara $4.49^{0}-4.50^{0}$ Lintang Selatan dan membentang dari barat ketimur diantara $122.42^{0}-122.43^{0}$ Bujur Timur.

Luas Wilayah

Tabel 3.2 Luas Wilayah Kecamatan Katobu

\begin{tabular}{cccc}
\hline No & Desa/Kelurahan & $\begin{array}{c}\text { Luas wilayah } \\
\left(\mathrm{Km}^{2)}\right.\end{array}$ & Persentase \\
\hline 1 & RahaI & 1,30 & 10,09 \\
\hline 2 & Laende & 1,25 & 9,70 \\
\hline 3 & FooKuni & 2,27 & 17,62 \\
\hline 4 & Watonea & 5,68 & 44,10 \\
\hline 5 & Butung-Butung & 0,56 & 4,35 \\
\hline 6 & RahaII & 0,56 & 4,35 \\
\hline 7 & Wamponiki & 0,55 & 4,27 \\
\hline 8 & . RahaIII & 0,71 & 5,51 \\
\hline & Jumlah & $\mathbf{1 2 , 8 8}$ & $\mathbf{1 0 0}$ \\
\hline
\end{tabular}

Sumber : Data diolah (2018)

Secara administratif, Kecamatan Katobu terdiri dari 8 kelurahan. Dari jumlah kelurahan yang ada,yang memiliki wilayah terluas 
adalah Kelurahan Watonea dengan luas $5,68 \mathrm{Km}^{2} \quad(44,10 \%), \quad$ sedangkan Kelurahan yang memiliki Wilayah terkecil adalah Kelurahan Wamponiki dengan luas $0,55 \mathrm{Km}^{2}(4,27 \%)$ dari luas Kecamatan Katobu.

\section{Iklim dan Cuaca}

Keadaan iklim di nyatakan sebagai keadaan rata -rata cuaca dalam periode waktu tertentu, sedangkan cuaca adalah keadaan atmosfer pada suatu saat. Keadaan iklim ini sangat di pengaruhi oleh suhu udara, kelembapan udara, tekanan udara, curah hujan, dan durasi sinar matahari. Faktor - faktor yang mempengaruhi iklim tersebut memberikan gambaran iklim di suatu tempat yang lain ( Bayong, 1990).

Kecamatan Katobu pada umumnya beriklim tropis dengan suhu rata - rata $25^{0}-27^{0} \mathrm{C}$. Seperti halnya daerah lain, pada bulan November sampai Juni angin bertiup dari benua Asia dan Samudra Pasifik mengandung banyak uap air yang menyebapkan terjadinya hujan di sebagian besar wilayah Indonesia, termasuk Kecamatan Katobu.

Sedangkan musim kemarau terjadi antara bulan juli dan oktober, dimana pada bulan ini angin bertiup dari benua Australia yang sifatnya kering dan sedikit mengandung uap air. Seperti halnya daerah Sulawesi Tenggara pada umumnya, di Kecamatan Katobu angin bertiup dengan arah yang tidak menentu pula, dan keadaan ini disebut musim pancaroba.

Musim hujan terjadi pada bulan November sampai dengan juni angin yang mengandung banyak uap air bertiup dari benua Asia dan Samudra pasifik sehingga menyebapkan hujan.

Kondisi Demografi

Demografi adalah ilmu yang mempelajari tentang susunan, jumlah dan perkembangan penduduk. Kondisi demografi berarti memberikan urayan atau gambaran statistic mengenai suatu bangsa dilihat dari sudut sosial politik atau ilmu kepend udukan. Kondisi demografi secara administratif, Kecamatan Katobu terdiri dari 7 Kelurahan, 28 lingkungan, dan 64 rukun tetangga menurut hasil pendataan pada tahun 2017 yaitu berjumlah 31.077 pada tahun 2017 jiwa yang terdiri dari 14.842 jiwa laki- laki dan 16.235 jiwa perempuan . secara terperinci keadaan penduduk Kecamatan katobu dapat di uraikan menurut umur dan jenis kelamin, tingkat pendidikan, dan mata pencaharian.

\section{HASIL PENELITIAN}

Tabel 4.1 Tingkat Kesehatan Responden

\begin{tabular}{llcc}
\hline No & Kondisi Kesehatan & Jumlah & $\begin{array}{c}\text { Persentase } \\
(\mathbf{\%})\end{array}$ \\
\hline 1 & Baik & 27 & 63 \\
\hline 2 & Kurang baik & 9 & 21 \\
\hline 3 & Buruk & 7 & 16 \\
\hline & Jumlah & $\mathbf{4 3}$ & $\mathbf{1 0 0}$ \\
\hline
\end{tabular}

Sumber : Data di olah 2018

Data di atas menunjukan bahwa pada umumnya responden yang mempunyai kondisi kesehatan yang baik, yang meliputi kesehatan 
keluarga, lingkungan dan masyarakat sebanyak 27 responden atau dalam persentase $63 \%$. Namun demikian terdapat pula responden yang memiliki kondisi kesehatan yang kurang baik, dimana responden yang memiliki kondisi kesehatan yang kurang baik sebanyak 9 responden atau dalam persentase $21 \%$. Sedangkan responden yang memiliki kondisi kesehatan yang buruk sebanyk 7 responden atau dalam persentase 16 $\%$.

Tabel 4.2 Tingkat Keamanan

\begin{tabular}{cccc}
\hline No & Pernyataan Responden & Jumlah & Persentase (\%) \\
\hline 1 & Tidak aman & 17 & 40 \\
\hline 2 & Aman & 7 & 16 \\
\hline 3 & Sangat tidak aman & 19 & 44 \\
\hline & Jumlah & $\mathbf{4 3}$ & $\mathbf{1 0 0}$ \\
\hline
\end{tabular}

Sumber: data diolah pada tahun 2018

Dari tabel di atas dapat di uraikan dari 43 responden yang merasa tidak aman sebanyak 17 responden atau dalam persentase $40 \%$, sedangkan responden yang merasa aman aman sebanyak 7 rsesponden atau dalam persentase $16 \%$, dan responden yang merasa tidak aman sebanyak 19 responden atau dalam persentase $44 \%$. Hal ini di sebapkan karena daerah yang di jadikan sebagai tempat meneliti adalah daerah yang sering terjadinya tingkat kejahatan.

Tabel 4. 3 Interaksi Sosial

\begin{tabular}{cccc}
\hline No & Pernyataan Responden & Jumlah & Persentase (\%) \\
\hline 1 & Baik & 39 & 91 \\
\hline 2 & Tidak baik & 4 & 9 \\
\hline 3 & Sangat tidak baik & - & - \\
\hline & Jumlah & $\mathbf{4 3}$ & $\mathbf{1 0 0}$
\end{tabular}

Sumber:Data diolah pada tahun 2018

Pada tabel tersebut dapat diuraikan responden yang memiliki interaksi sosial yang baik sebanyak 39 responden atau dalam persentase $91 \%$, dan yang responden yang memiliki sedangkan responden yang memiliki interaksi soasial yang sangat tidak baik tidak ada.

Luas Lahan komunikasi yang tidak baik hanya 4 responden atau dalam persentase $9 \%$,

Tabel 4.4 Luas Alih Fungsi Lahan Hutan Warangga

\begin{tabular}{cccc}
\hline No & Tahun & \multicolumn{2}{c}{ Alih Fungsi Lahan } \\
\hline & & Sebelum $(\mathrm{Ha})$ & Sesudah $(\mathrm{Ha})$ \\
\hline 1 & 2015 & 107.119 & 94.073 \\
\hline 2 & 2016 & 44.214 & 22.991 \\
\hline 3 & 2017 & 24.103 & 18.138 \\
\hline 4 & 2018 & 1.270 & 870
\end{tabular}

Sumber : Data diolah 2018

Berdasarkan tabel diatas yang bersumber dari Surat Keputusan

Gubernur Sulawesi Tenggara Nomor 115 Tahun 2018 dapat di jelaskan 
bahwa pada tahun 2015 luas hutan warangga sebelum di alih fungsikan seluas $107.119 \mathrm{Ha}$, setelah di alih fungsikan menjadi 94. $073 \mathrm{Ha}$, untuk tahun 2016 jumlah luas lahan hutan warangga sebelum di alih fungsikan seluas 44. $214 \mathrm{Ha}$, sedangkan setelah di alih fungsikan menjadi 22. $991 \mathrm{Ha}$, untuk tahun 2017 luas hutan warangga sebelum di alih fungsikan seluas 24 . $103 \mathrm{Ha}$, sedangkan pada tahun 2018 luas hutan warangga sebelum di alih fungsikan seluas $1.270 \mathrm{Ha}$, sedangkan sesudah di alih fungsikan lahan hutan warangga menjadi $870 \mathrm{Ha}$.

\section{Pendapatan}

Pendapatan adalah jumlah uang yang di terima dari aktivitasnya, kebanyakan dari penjualan produk dana jasa kepada pelanggan. Sedangkan bagi masyarakat petani jagung oleh masyarakat yang tinggal di Kecamatan Katobu Kabupaten Muna adalah penerimaan yang di peroleh dari hasil petani jagung yang telah di kerjakan. Responden dalam penelitian ini umumnya bermata pencaharian sebagai petani jagung .

Pendapatan adalah penerimaan yang di terima oleh responden sebagai imbalan atas sesuatu pekerjaan atau jasa yang telah di lakukan setelah di kurangi dengan pengeluaran.Dari hasil penelitian yang di peroleh bahwa pendapatan yang di terima responden bervariasi sesuai dengan pendapatan pekerjaan pokok yang di tekuni oleh mereka untuk memenuhi kebutuhan hidup keluarga. Berikut ini jumlah pendapatan setiap kali panen (3 bulan) petani jagung yang tinggal di sekitar Kecamatan Katobu Kabupaten Muna.

Tabel 4.5 Biaya Pengeluaran Per Sekali Tanam

\begin{tabular}{cccccc}
\hline No & $\begin{array}{c}\text { Pengeluaran } \\
\text { tiap kali panen }\end{array}$ & Satuan & $\begin{array}{c}\text { Harga } \\
\text { satuan } \\
(\mathbf{R p})\end{array}$ & Jumlah & $\begin{array}{c}\text { Harga } \\
\text { Produksi } \\
\text { (Rp) }\end{array}$ \\
\hline 1 & Bibit & Liter & 10.000 & 2 & 20.000 \\
\hline 2 & Cangkul & Unit & 70.000 & 2 & 140.000 \\
\hline 3 & Tembilang & Unit & 45.000 & 2 & 135.000 \\
\hline 4 & Parang & Unit & 35.000 & 2 & 70.000 \\
\hline 5 & Karung & Unit & 6.000 & 7 & 42.000 \\
\hline 6 & Keranjang Besar & Unit & 35.000 & 2 & 70.000 \\
\hline 7 & Pupuk & Kg & 17.000 & 4 & 68.000 \\
\hline 8 & Ember & Unit & 25.000 & 4 & 100.000 \\
\hline 9 & Alat Penyemprot & Unit & 285.000 & 1 & 285.000 \\
\hline 10 & Tenaga & Orang & 50.000 & 3 & 150.000 \\
\hline $\begin{array}{c}\text { Total Biaya } \\
\text { (TC) }\end{array}$ & & $\mathbf{5 7 8 . 0 0 0}$ & $\mathbf{3 2}$ & $\mathbf{9 6 8 . 0 0 0 , -}$ \\
Total & & - & - & $\mathbf{4 . 8 6 5 . 0 0 0}$ \\
& $\begin{array}{c}\text { Penimaan } \\
\text { ( TR) }\end{array}$ & & & & \\
\hline
\end{tabular}

Sumber : Data diolah tahun 2018 


\section{PEMBAHASAN}

Berdasarkan hasil analisis dampak pengalih fungsian hutan jati menjadi lahan pertanian jagung terhadap kondisi sosial ekonomi masyaraat di sekitar Kecamatan Katobu Kabupaten Muna menunjukan kondisi sosial ekonomi yang terbagi menjadi dua yaitu kondisi sosial yang terdiri dari kondisi kesehatan, interaksi sosial, tingkat keamanan,luas lahan sedangkan kondisi ekonomi yang terdiri dari pendapatan.

Di lihat dari kondisi kesehatan dari 43 responden, yang memiliki kondisi kesehatan yang baik sebanyak 27 responden atau dalam persentase 63 $\%$. Namun demikian terdapat pula responden yang memiliki kondisi kesehatan yang kurang baik, dimana responden yang memiliki kondisi kesehatan yang kurang baik sebanyak 9 responden atau dalam persentase 21 $\%$. Sedangkan responden yang memiliki kondisi kesehatan yang buruk sebanyak 7 responden atau dalam persentase $16 \%$. Reseponden yang terserang penyakit yang sering, kadang kadang maupun tidak pernah. Hal ini dapat di sebapkan karena pergantian musim yang tidak menentu. Akan tetapi ada beberapa responden yang memiliki penyakit tersebut. Dari hasil penelitian di lapangan menunjukan bahwa keadaan kesehatan masyarakat telah memiliki kesadaran tentang pemanfaatan jasa atau pelayanan pusat kesehatan masayarakat (Rumah Sakit) pada umumnya masyarakat bila terserang penyakit selalu berobat ke Rumah Sakit atau pada pada petugas kesehatan yang ada.

Di lihat dari tingkat keamanan dapat di uraikan dari 43 responden yang merasa tidak aman sebanyak 17 responden atau dalam persentase 40
$\%$, sedangkan responden yang merasa aman aman sebanyak 7 rsesponden atau dalam persentase $16 \%$, dan responden yang merasa tidak aman sebanyak 19 responden atau dalam persentase $44 \%$. Hal ini di sebapkan karena daerah yang di jadikan sebagai tempat meneliti adalah daerah yang sering terjadinya tingkat kejahatan.

Di lihat dari interaksi sosial, responden yang memiliki interaksi sosial yang baik semakin banyak. Hal ini dapat di sebapkan masyarakat menyadari seberapa pentingnya interaksi sosial di perlukan dalam bermasyarakat. Sedangkan responden yang memiliki responden yang tidak baik, hal ini di karenakan sebagian responden sebagian menetap di kebun dan menjaga tanaman jagung agar tidak di ganggu oleh hama-hama sehingga dapat menyebapkan jagung tersebut gagal panen.

Di lihat dari luas lahan hutan jati warangga adalah sekitar $\pm 130 \mathrm{Ha}$, sedangkan yang di gunakan dalam lahan pertanian jagung sadalah sekitar $\pm 10 \mathrm{Ha}$. Hal ini dapat membantu lahan tersebut untuk tidak manjadi lahan kering. Di sisi lain di dukung juga oleh kebijakan dari pemerintah bahwa lahan hutan warangga dapat di gunakan sebagai lahan pertanian jagung mengingat pemerintah berencana lahan pertanian jagung akan menjadi sebuah gerakan masyarakat karena memiliki potensi besar untuk meningkatkan kesejahteraan petani atau warga yang konsentrasi menanam tanaman jagung, serta dapat jadikan sebagai pendapatan untuk daerah.

Di lihat dari segi pendapatan jelaskan jumlah pendapatan petani jagung yang tinggal di Kecamatan Katobu Kabupaten Muna yang mempunyai jumlah pendapatan hail panen jagung sebesar Rp 500, 000 $\mathrm{Rp}$ 1. 000, 000 adalah 4 responden 
atau dalam persentase $9 \%$, kemudian jumlah pendapatan petani jagung yang mempunyai pndapatan setiap kali panen sebesar Rp 1. 500,000 - Rp 2. 000,000 adalah 18 responden atau dalam persentase $42 \%$, sedangkan jumlah pendapatan petani jagung yang mempunyai pendapatan sebesar Rp 2 . 500,000 - Rp 3.000,000 adalah 15 responden atau dalam persentase 35 $\%$, dan jumlah pendapatan yang mempunyai pendapatan sebesar $\geq \mathrm{Rp}$ $3.000,000$ sebanyak 6 responden atau dalam persentase $14 \%$. Adanya perbedaan jumlah pendapatan pertanian jagung yang tinggal di Kecamatan Katobu Kabupaten Muna hal ini di sebabkan karena sebagian dari lahan pertanian jagung tersebut di makan oleh hama seperti monyet dan babi. Sehingga mengurangi hasil panen jagung. Di sisi lain, jumlah pendapatan tersebut bukan hanya di dapatkan sebagai pertanian jagung akan tetapi ada tanaman lain yang di tanam seperti sayur - sayuran, tanaman pisang serta tanaman lainnya. untuk di manfaatkan oleh masyarakat pertanian jagung seperti di jual di pasaran.

\section{KESIMPULAN}

Adapun yang dapat di simpulkan dari penelitian ini dapat di uraikan sebagai berikut :

1. Dari hasil penelitian di lapangan menunjukan bahwa keadaan kesehatan masyarakat telah memiliki kesadaran tentang pemanfaatan jasa atau pelayanan pusat kesehatan masayarakat (Rumah Sakit) pada umumnya masyarakat bila terserang penyakit selalu berobat ke Rumah Sakit atau pada pada petugas kesehatan yang ada. Dari 43 responden, yang memiliki kondisi kesehatan yang baik sebanyak 27 responden atau dalam persentase $63 \%$.

2. Tingkat keamanan dapat di uraikan dari 43 responden yang merasa tidak aman sebanyak 17 responden atau dalam persentase $40 \%$. Perlu adanya perhatian dari pemerintah.

3. Di lihat dari interaksi sosial, responden yang memiliki interaksi sosial yang baik semakin banyak. Hal ini di lihat responden yang memiliki interaksi sosial yang baik sebanyak 39 responden atau dalam persentase $91 \%$.

4. Di lihat dari luas lahan hutan jati warangga adalah sekitar $\pm 130 \mathrm{Ha}$, sedangkan yang di gunakan dalam lahan pertanian jagung sadalah sekitar \pm 10 Ha.

Dari 43 responden jumlah pendapatan petani jagung yang mempunyai pndapatan setiap kali panen sebesar Rp 1. 500,000 - Rp 2 . 000,000 adalah 18 responden atau dalam persentase $42 \%$.

\section{DAFTAR PUSTAKA}

Agustin Barbara. (1994). Kamus Lengkap Bahasa Inggris. Surabaya: Mega Press.

Herman Soesangobeng. (2002). Sinkronisasi Peraturan Perundang-undangan Mengenai Pengelolaan Sumberdaya Alam.

Munir, Mishabul (2008), Pengsaruh Konversi Lahan Pertanian Terhadap Tingkat Kesejahteraan Ruma htangga Petani, Skripsi, 
Jurnal Penelitian Pendidikan Geografi Volume 4. No 2 April 2019

Sarjana Pertanian Institut Pertanian Bogor.

Muhamad Yudhistira Dika (2013). Analisis Dampak Alih Fungsi Lahan Pertanian Terhadap Ketahanan Pangan di Kabupaten Bekasi Jawa Barat.

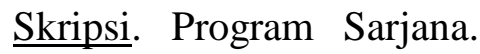
Institut Pertanian Bogor. Bogor.

Nurmala Tati, dkk .(2012). Pengantar IlmuPertanian.Yogyakarta :Graha Ilmu.

Santoso, Urip. (2005). Hukum Agraria dan Hak-Hak atas Tanah. Jakarta: Kecana.

Soemarwoto. (2003). Analisis Mengenai Dampak Lingkungan.Yogyakarta : Gaja Mada University Press

Soekartawi.(1995). Analisis Usaha Tani. Jakarta : UI Press.

Widodo, Erna dan Mukhtar (2000). Konstruksi ke Arah Penelitian Deskriptif. Yogyakarta : Avaroz. 